Article

\title{
Enantiomeric Composition, Antioxidant Capacity and Anticholinesterase Activity of Essential Oil from Leaves of Chirimoya (Annona cherimola Mill.)
}

\author{
Eduardo Valarezo*(D), Jeannette Ludeña, Estefanía Echeverria-Coronel, Luis Cartuche (D), Miguel Angel Meneses (D), \\ James Calva (D) and Vladimir Morocho (D)
}

check for updates

Citation: Valarezo, E.; Ludeña, J.; Echeverria-Coronel, E.; Cartuche, L.; Meneses, M.A.; Calva, J.; Morocho, V. Enantiomeric Composition, Antioxidant Capacity and Anticholinesterase Activity of Essential Oil from Leaves of Chirimoya (Annona cherimola Mill.).

Plants 2022, 11, 367. https://doi.org/ $10.3390 /$ plants 11030367

Academic Editors: Hazem Salaheldin Elshafie, Laura De

Martino and Adriano Sofo

Received: 20 December 2021

Accepted: 26 January 2022

Published: 28 January 2022

Publisher's Note: MDPI stays neutral with regard to jurisdictional claims in published maps and institutional affiliations.

Copyright: (C) 2022 by the authors. Licensee MDPI, Basel, Switzerland. This article is an open access article distributed under the terms and conditions of the Creative Commons Attribution (CC BY) license (https:// creativecommons.org/licenses/by/ $4.0 /)$
Departamento de Química, Universidad Técnica Particular de Loja, Loja 110150, Ecuador; isah4a@hotmail.com (J.L.); beecheverria@utpl.edu.ec (E.E.-C.); lecartuche@utpl.edu.ec (L.C.); mameneses@utpl.edu.ec (M.A.M.); jwcalva@utpl.edu.ec (J.C.); svmorocho@utpl.edu.ec (V.M.)

* Correspondence: bevalarezo@utpl.edu.ec; Tel.: +593-7-3701444

Abstract: Annona cherimola Mill. is a native species of Ecuador cultivated worldwide for the flavor and properties of its fruit. In this study, hydrodistillation was used to isolate essential oil (EO) of fresh Annona cherimola leaves collected in Ecuadorian Sierra. The EO chemical composition was determined using a non-polar and a polar chromatographic column and enantiomeric distribution with an enantioselective column. The qualitative analysis was carried out by gas chromatography coupled to a mass spectrometer and quantitative analysis using gas chromatography equipped with a flame ionization detector. The antibacterial potency was assessed against seven Gram-negative bacteria and one Gram-positive bacterium. ABTS and DPPH assays were used to evaluate the radical scavenging properties of the EO. Spectrophotometric method was used to measure acetylcholinesterase inhibitory activity. GC-MS analysis allowed us to identify more than $99 \%$ of the EO chemical composition. Out of the fifty-three compounds identified, the main were germacrene D $(28.77 \pm 3.80 \%)$, sabinene $(3,9.05 \pm 1.69 \%), \beta$-pinene $(4,7.93 \pm 0.685),(E)$-caryophyllene $(10.52 \pm 1.64 \%)$ and bicyclogermacrene $(11.12 \pm 1.39 \%)$. Enantioselective analysis showed the existence of four pairs of enantiomers, the (-)- $\beta$-Pinene (1S, 5S) was found pure (100\%). Chirimoya essential oil exhibited a strong antioxidant activity and a very strong anticholinesterase potential with an $\mathrm{IC}_{50}$ value of $41.51 \pm 1.02 \mu \mathrm{g} / \mathrm{mL}$. Additionally, EO presented a moderate activity against Campylobacter jejuni and Klebsiella pneumoniae with a MIC value of $500 \mu \mathrm{g} / \mathrm{mL}$.

Keywords: essential oil; Annona cherimola; chemical composition; enantioselective analysis; antibacterial activity; antioxidant activity; anticholinesterase activity; germacrene D; Campylobacter jejuni

\section{Introduction}

Worldwide, the Annonaceae family comprises more than 128 genera and approximately 2106 species and they are mainly distributed in tropical and subtropical regions [1]. For Ecuador, 25 genera, 106 species and 20 endemic species are reported [2]. In a review of the antimalarial properties of the Annonaceae family, 11 species from Annona and Xilopia genus were recognized for their antiparasitic potential. Annonaceae species used in traditional medicine, over the tropical regions, are well documented for having potential for the treatment of parasitic diseases such as Malaria, Chagas and Leishmaniasis as well as other illnesses [3]. Indeed, Annona muricata was one of the most cited species with a variety of medicinal properties including the treatment for the symptoms of malarial infection, fever, liver ailments and headaches [4].

Annona cherimola, A. crassiflora, A. muricata, $A$. squamosa and $A$. reticulata are the commercial species, highly valued by their exotic edible fruit. Furthermore, different parts of the tree from these species have been used in folk medicine to treat several conditions including gastrointestinal diseases, diabetes and hypertension [5]. Many secondary metabolites have 
been reported such as phenols and other bioactive compounds but, the main chemical marker of the genus is a diverse group of polyketides called acetogenins, compounds closely associated to their antiproliferative effect on cancer cell lines $[5,6]$.

In a related study, nine species from Annona genus, including A. cherimola, where reviewed in relation to their phytochemical composition and biological activity and found that mainly polar extracts obtained from these plants, induce a reduction in blood sugar levels in chemically induced type-2 diabetic rats which demonstrate the antidiabetic potential of species from this genus. Likewise, seven out of nine of the studied species reported a good antioxidant capacity profile in different in vitro assays. A. cherimola was only tested trough the oxygen radical absorbance capacity (ORAC) assay [7].

Annona cherimola Mill. is a native shrub, widely distributed in the Andean, Coastal, Amazon and Insular regions of Ecuador, between 0-3000 $\mathrm{m}$ a.s.1 [2]. Currently, this species is cultivated in the subtropical and tropical regions worldwide, especially for its fruit, which is considered exotic. The A. cherimola species is commonly known as "chirimoya" or "chirimoyo" (Spanish language) and "custard-apple" (English language) [8]. The vernacular name "chirimoya" is derived from the Quechua (indigenous language) word "chirimuya", "chiri" that means cold and "muya" seeds. The fruit of this species is considered one the most appreciated inside the genus. The plant has been used in traditional medicine for the treatment of boils and others skin diseases [9].

Anthropological evidence suggests that the species $A$. cherimola was cultivated since the times of the Incan Empire and its fruit was considered as an active ingredient in the their diet [10]. Some important compounds have been isolated from this species such as alkaloids as cherimoline, annocherine A, annocherine B, cherianoine and rumocosine $\mathrm{H}$ [11], and some amides as cherinonaine, cheritamide, (N-trans-feruloyltyramine, $\mathrm{N}$-trans-caffeoyltyramine, N-cis-caeoyltyramine, dihydro feruloyltyramine, N-transferuloylmethoxytyramine, $\mathrm{N}$-cis-feruloylmethoxytyramine, and $\mathrm{N}-p$-coumaroyltyramine [12] Recent studies have shown that custard apple leaves contain flavonoids and other phenolic compounds with biological properties $[13,14]$ and that alcoholic extracts from the leaves have proapoptotic and antidepressant activities [15].

Several studies on the species of the Annona genus have reported the occurrence of compounds with potential application for pharmaceuticals, food, agrochemicals products and cosmetics $[3,5,6,16]$. Extracts from these species are used for a wide range of beneficial purposes, however, the research have been focused mainly on the non-volatile fraction of the fruits, meanwhile, the enantiomeric distribution and biological properties of the EOof Annona cherimola have not been reported previously. This fact stimulated our interest in studying the chemical composition, enantiomeric distribution and antimicrobial, antioxidant and anticholinesterase activities of the essential oil of custard apple leaves.

\section{Results}

A total of $15,150 \mathrm{~g}$ of fresh custard apple leaves, with a moisture of $53 \pm 5 \%(w / w)$, were used as raw material for the extraction. The isolation of the essential oil was carried out by hydrodistillation using a Clevenger-type apparatus. The amount of EO obtained was $38.5 \mathrm{~mL}$, which represents a yield of $0.25 \pm 0.02(v / w)$.

\subsection{Physical Properties of Essential Oil}

The essential oil isolated from leaves of $A$. cherimola was presented as a viscous liquid with a characteristic texture. The physical properties of EO are shown in Table 1. In addition, this table shows the subjective color and its RGB and CMYK values.

\subsection{Chemical Constituents of the Essential Oil}

The compounds ocurring in A. cherimola EO were identified and quantified by GCMS and GC-FID using nonpolar and polar columns. The Table 2 shows the quantitative and qualitative data of chemical constituents of custard apple obtained using nonpolar column DB-5ms. In the essential oil from chirimoya leaves fifty-three compounds were 
identified, which represent $99.80 \%$ of the total composition. According to their chemical nature, all the compounds were grouped in aliphatic monoterpene hydrocarbons (ALM), oxygenated monoterpenes (OXM), aliphatic sesquiterpene hydrocarbons (ALS) and oxygenated sesquiterpene (OXS). The ALS were the most representative compounds with twenty-seven compounds, which represents $69.40 \%$, followed by ALM with $25.68 \%$. Compounds belonging to the aromatic monoterpene hydrocarbons, aromatic sesquiterpene hydrocarbons and oxygenated sesquiterpene groups were not identified. The ALS germacrene $\mathrm{D}$ (compound 32, CF: $\mathrm{C}_{15} \mathrm{H}_{24}, \mathrm{MM}: 204.19 \mathrm{Da}$ ) was the main constituent with $28.77 \pm 3.80 \%$. Other main compounds ( $>5 \%)$ were sabinene $(3,9.05 \pm 1.69 \%), \beta$-pinene $(4,7.93 \pm 0.68 \%)$, (E)-caryophyllene $(24,10.52 \pm 1.645)$ and bicyclogermacrene $(36,11.12 \pm 1.39 \%)$. Compounds 8 and 9 (limonene and $\beta$-phellandrene) co-eluted, both representing $0.66 \pm 0.13 \%$.

Table 1. Physical properties of the essential oil.

\begin{tabular}{ccc}
\hline & \multicolumn{2}{c}{ Annona cherimola EO } \\
\cline { 2 - 3 } & Mean $^{\mathbf{a}}$ & SD $^{\mathbf{b}}$ \\
\hline Density, $\rho\left(\mathrm{g} / \mathrm{cm}^{3}\right)$ & 0.9472 & 0.0044 \\
Refractive index, $n^{20}$ & 1.4713 & 0.0023 \\
Specific rotation, $[\alpha]\left(^{\circ}\right)$ & -61.8 & 0.8 \\
Subjective color & Light-yellow & \\
RGB color values & R:255, G:255, B:224 & \\
CMYK color values & $\mathrm{C}: 0, \mathrm{M}: 0, \mathrm{Y}: 0.12, \mathrm{~K}: 0$ & \\
\hline
\end{tabular}

${ }^{a}$ Mean of nine determinations: three distillations $\times$ three collections, ${ }^{\mathrm{b}}$ Standard deviation.

Table 2. Chemical composition of essential oil from Annona cherimola leaves.

\begin{tabular}{|c|c|c|c|c|c|c|c|c|c|}
\hline \multirow{2}{*}{$\mathrm{CN}$} & \multirow{2}{*}{ RT } & \multirow{2}{*}{ Compounds } & \multirow{2}{*}{ RI } & \multirow{2}{*}{ RI $^{\text {ref }}$} & \multicolumn{2}{|c|}{ A. chirimola $\mathrm{EO}$} & \multirow{2}{*}{ Type } & \multirow{2}{*}{$\mathrm{CF}$} & \multirow{2}{*}{ MM (Da) } \\
\hline & & & & & $\%$ & SD & & & \\
\hline 1 & 5.73 & $\alpha$-Thujene & 924 & 924 & 0.89 & 0.15 & ALM & $\mathrm{C}_{10} \mathrm{H}_{16}$ & 136.1 \\
\hline 2 & 5.94 & $\alpha$-Pinene & 932 & 932 & 4.02 & 0.36 & ALM & $\mathrm{C}_{10} \mathrm{H}_{16}$ & 136.1 \\
\hline 3 & 7.37 & Sabinene & 969 & 969 & 9.05 & 1.69 & ALM & $\mathrm{C}_{10} \mathrm{H}_{16}$ & 136.1 \\
\hline 4 & 7.50 & $\beta$-Pinene & 973 & 974 & 7.93 & 0.68 & ALM & $\mathrm{C}_{10} \mathrm{H}_{16}$ & 136.1 \\
\hline 5 & 8.13 & Myrcene & 987 & 988 & 0.78 & 0.19 & ALM & $\mathrm{C}_{10} \mathrm{H}_{16}$ & 136.1 \\
\hline 6 & 8.72 & $\alpha$-Phellandrene & 1001 & 1002 & 0.11 & 0.03 & ALM & $\mathrm{C}_{10} \mathrm{H}_{16}$ & 136.1 \\
\hline 7 & 9.15 & $\alpha$-Terpinene & 1013 & 1014 & 0.14 & 0.04 & ALM & $\mathrm{C}_{10} \mathrm{H}_{16}$ & 136.1 \\
\hline 8,9 & 9.64 & Limonene $+\beta$-Phellandrene ${ }^{a}$ & 1023 & 1024 & 0.66 & 0.13 & ALM & $\mathrm{C}_{10} \mathrm{H}_{16}$ & 136.1 \\
\hline 10 & 10.08 & (Z)- $\beta$-Ocimene & 1032 & 1032 & 0.84 & 0.23 & ALM & $\mathrm{C}_{10} \mathrm{H}_{16}$ & 136.1 \\
\hline 11 & 10.54 & (E)- $\beta$-Ocimene & 1043 & 1044 & 0.73 & 0.12 & ALM & $\mathrm{C}_{10} \mathrm{H}_{16}$ & 136.1 \\
\hline 12 & 10.93 & $\gamma$-Terpinene & 1053 & 1054 & 0.46 & 0.13 & ALM & $\mathrm{C}_{10} \mathrm{H}_{16}$ & 136.1 \\
\hline 13 & 12.15 & Terpinolene & 1083 & 1086 & 0.07 & 0.01 & ALM & $\mathrm{C}_{10} \mathrm{H}_{16}$ & 136.1 \\
\hline 14 & 13.10 & Linalool & 1099 & 1095 & 0.17 & 0.01 & OXM & $\mathrm{C}_{10} \mathrm{H}_{18} \mathrm{O}$ & 154.1 \\
\hline 15 & 16.55 & Terpinen-4-ol & 1176 & 1174 & 0.07 & 0.01 & OXM & $\mathrm{C}_{10} \mathrm{H}_{18} \mathrm{O}$ & 154.1 \\
\hline 16 & 23.00 & Bicycloelemene & 1332 & 1330 & 0.33 & 0.07 & ALS & $\mathrm{C}_{15} \mathrm{H}_{24}$ & 204.2 \\
\hline 17 & 23.17 & $\delta$-Elemene & 1337 & 1335 & 1.26 & 0.41 & ALS & $\mathrm{C}_{15} \mathrm{H}_{24}$ & 204.2 \\
\hline 18 & 23.66 & $\alpha$-Cubebene & 1348 & 1345 & 0.46 & 0.11 & ALS & $\mathrm{C}_{15} \mathrm{H}_{24}$ & 204.2 \\
\hline 19 & 24.81 & $\alpha$-Copaene & 1377 & 1374 & 3.06 & 0.77 & ALS & $\mathrm{C}_{15} \mathrm{H}_{24}$ & 204.2 \\
\hline 20 & 25.17 & $\beta$-Panasinsene & 1384 & 1381 & 0.14 & 0.04 & ALS & $\mathrm{C}_{15} \mathrm{H}_{24}$ & 204.2 \\
\hline 21 & 25.38 & $\beta$-Cubebene & 1389 & 1387 & 1.38 & 0.27 & ALS & $\mathrm{C}_{15} \mathrm{H}_{24}$ & 204.2 \\
\hline 22 & 25.49 & $\beta$-Elemene & 1391 & 1389 & 2.41 & 0.62 & ALS & $\mathrm{C}_{15} \mathrm{H}_{24}$ & 204.2 \\
\hline 23 & 25.99 & (Z)-Caryophyllene & 1406 & 1408 & 0.04 & 0.01 & ALS & $\mathrm{C}_{15} \mathrm{H}_{24}$ & 204.2 \\
\hline 24 & 26.59 & (E)-Caryophyllene & 1419 & 1417 & 10.52 & 1.64 & ALS & $\mathrm{C}_{15} \mathrm{H}_{24}$ & 204.2 \\
\hline 25 & 27.05 & $\beta$-Gurjunene & 1429 & 1431 & 0.10 & 0.02 & ALS & $\mathrm{C}_{15} \mathrm{H}_{24}$ & 204.2 \\
\hline 26 & 27.16 & $\gamma$-Elemene & 1432 & 1434 & 0.20 & 0.04 & ALS & $\mathrm{C}_{15} \mathrm{H}_{24}$ & 204.2 \\
\hline 27 & 27.59 & $\alpha$-Guaiene & 1439 & 1437 & 0.12 & 0.03 & ALS & $\mathrm{C}_{15} \mathrm{H}_{24}$ & 204.2 \\
\hline 28 & 27.86 & Aromadendrene & 1443 & 1439 & 0.33 & 0.08 & ALS & $\mathrm{C}_{15} \mathrm{H}_{24}$ & 204.2 \\
\hline 29 & 28.06 & $\alpha$-Humulene & 1453 & 1452 & 2.05 & 0.51 & ALS & $\mathrm{C}_{15} \mathrm{H}_{24}$ & 204.2 \\
\hline 30 & 28.22 & allo-Aromadendrene & 1457 & 1458 & 0.20 & 0.03 & ALS & $\mathrm{C}_{15} \mathrm{H}_{24}$ & 204.2 \\
\hline
\end{tabular}


Table 2. Cont.

\begin{tabular}{|c|c|c|c|c|c|c|c|c|c|}
\hline \multirow{2}{*}{$\mathrm{CN}$} & \multirow{2}{*}{ RT } & \multirow{2}{*}{ Compounds } & \multirow{2}{*}{ RI } & \multirow{2}{*}{$\mathrm{RI}^{\mathrm{ref}}$} & \multicolumn{2}{|c|}{ A. chirimola EO } & \multirow{2}{*}{ Type } & \multirow{2}{*}{$\mathrm{CF}$} & \multirow{2}{*}{ MM (Da) } \\
\hline & & & & & $\%$ & SD & & & \\
\hline 31 & 28.78 & 4,5-di-epi-Aristolochene & 1470 & 1471 & $\operatorname{tr}$ & - & ALS & $\mathrm{C}_{15} \mathrm{H}_{24}$ & 204.2 \\
\hline 32 & 29.01 & $\gamma$-Gurjunene & 1475 & 1475 & 0.45 & 0.07 & ALS & $\mathrm{C}_{15} \mathrm{H}_{24}$ & 204.2 \\
\hline 33 & 29.20 & Germacrene D & 1478 & 1480 & 28.77 & 3.80 & ALS & $\mathrm{C}_{15} \mathrm{H}_{24}$ & 204.2 \\
\hline 34 & 29.46 & $\beta$-Selinene & 1486 & 1489 & 0.38 & 0.12 & ALS & $\mathrm{C}_{15} \mathrm{H}_{24}$ & 204.2 \\
\hline 35 & 29.56 & $\gamma$-Amorphene & 1493 & 1495 & 0.20 & 0.08 & ALS & $\mathrm{C}_{15} \mathrm{H}_{24}$ & 204.2 \\
\hline 36 & 29.74 & Bicyclogermacrene & 1497 & 1500 & 11.12 & 1.39 & ALS & $\mathrm{C}_{15} \mathrm{H}_{24}$ & 204.2 \\
\hline 37 & 29.96 & $\alpha$-Muurolene & 1501 & 1500 & 0.39 & 0.07 & ALS & $\mathrm{C}_{15} \mathrm{H}_{24}$ & 204.2 \\
\hline 38 & 30.17 & Germacrene A & 1506 & 1508 & 1.37 & 0.35 & ALS & $\mathrm{C}_{15} \mathrm{H}_{24}$ & 204.2 \\
\hline 39 & 30.49 & $\delta$-Amorphene & 1510 & 1511 & 0.41 & 0.07 & ALS & $\mathrm{C}_{15} \mathrm{H}_{24}$ & 204.2 \\
\hline 40 & 30.63 & $\gamma$-Cadinene & 1512 & 1513 & 0.37 & 0.11 & ALS & $\mathrm{C}_{15} \mathrm{H}_{24}$ & 204.2 \\
\hline 41 & 30.73 & $\delta$-Cadinene & 1517 & 1522 & 1.79 & 0.39 & ALS & $\mathrm{C}_{15} \mathrm{H}_{24}$ & 204.2 \\
\hline 42 & 31.26 & trans-Cadina-1,4-diene & 1530 & 1533 & 0.09 & 0.02 & ALS & $\mathrm{C}_{15} \mathrm{H}_{24}$ & 204.2 \\
\hline 43 & 32.03 & Elemol & 1546 & 1548 & 0.13 & 0.07 & OXS & $\mathrm{C}_{15} \mathrm{H}_{26} \mathrm{O}$ & 222.2 \\
\hline 44 & 32.14 & Germacrene B & 1554 & 1559 & 1.45 & 0.24 & ALS & $\mathrm{C}_{15} \mathrm{H}_{24}$ & 204.2 \\
\hline 45 & 32.75 & (E)-Nerolidol & 1563 & 1561 & 0.54 & 0.08 & OXS & $\mathrm{C}_{15} \mathrm{H}_{26} \mathrm{O}$ & 222.2 \\
\hline 46 & 32.97 & Germacrene D-4-ol & 1571 & 1574 & 1.41 & 0.42 & OXS & $\mathrm{C}_{15} \mathrm{H}_{26} \mathrm{O}$ & 222.2 \\
\hline 47 & 33.45 & Carotol & 1590 & 1594 & 0.08 & 0.02 & OXS & $\mathrm{C}_{15} \mathrm{H}_{26} \mathrm{O}$ & 222.2 \\
\hline 48 & 33.70 & Ledol & 1597 & 1602 & 1.12 & 0.17 & OXS & $\mathrm{C}_{15} \mathrm{H}_{26} \mathrm{O}$ & 222.2 \\
\hline 49 & 34.75 & 1-epi-Cubenol & 1621 & 1627 & 0.18 & 0.02 & OXS & $\mathrm{C}_{15} \mathrm{H}_{26} \mathrm{O}$ & 222.2 \\
\hline 50 & 35.52 & cis-Cadin-4-en-7-ol & 1629 & 1635 & 0.12 & 0.01 & OXS & $\mathrm{C}_{15} \mathrm{H}_{26} \mathrm{O}$ & 222.2 \\
\hline 51 & 35.59 & epi- $\alpha$-Cadinol & 1632 & 1638 & 0.33 & 0.08 & OXS & $\mathrm{C}_{15} \mathrm{H}_{26} \mathrm{O}$ & 222.2 \\
\hline 52 & 36.00 & $\alpha$-Muurolol (=Torreyol) & 1640 & 1644 & 0.56 & 0.14 & OXS & $\mathrm{C}_{15} \mathrm{H}_{26} \mathrm{O}$ & 222.2 \\
\hline \multirow[t]{6}{*}{53} & 36.61 & $\alpha$-Cadinol & 1653 & 1652 & $\operatorname{tr}$ & - & OXS & $\mathrm{C}_{15} \mathrm{H}_{26} \mathrm{O}$ & 222.2 \\
\hline & & ALM & & & 25.68 & & & & \\
\hline & & OXM & & & 0.24 & & & & \\
\hline & & ALS & & & 69.40 & & & & \\
\hline & & OXS & & & 4.47 & & & & \\
\hline & & Total identified & & & 99.80 & & & & \\
\hline
\end{tabular}

RT: Retention Time; RI: Calculated Retention Indices; RI ref: References Retention Indices; SD: Standard Deviation; CF: Chemical Formula; MM: Monoisotopic Mass; tr: traces; -: not calculated. ${ }^{1}$ Co-eluted compounds.

Coeluting compounds (limonene and $\beta$-phellandrene) were separated using an HPINNOWax polar column. The retention index in this column for limonene was 1192 and for $\beta$-phellandrene was 1201. Limonene (mixture of $(+)$-limonene and $(-)$-limonene) presented a percentage of $0.55 \pm 0.09 \%$ and $\beta$-phellandrene a value of $0.12 \pm 0.01 \%$.

\subsection{Enantioselective Analysis}

The enantioselective analysis from Annona cherimola $\mathrm{EO}$ was achieved for the first time. The Table 3 shows the enantiomeric distribution, linear retention indices and enantiomeric excess (e.e.) of each enantiomer. Using a chiral column could be quantified four pairs of enantiomers, whose peaks were well separated at the base. The $\beta$-pinene $(-)$ was found practically pure, while $(-)$ - $\alpha$-pinene and $(-)$-sabinene and $(-)$-germacrene $\mathrm{D}$ exhibited a high enantiomeric excess, whereas $(-)$-limonene and $(+)$-limonene were found in a racemic mixture.

\subsection{Antibacterial Activity}

Microdilution broth method was used to assess the antibacterial activity of essential oil of A. cherimola leaves. Tetracycline was used as a positive control and the maximum evaluated concentration was $1000 \mu \mathrm{g} / \mathrm{mL}$. The minimum inhibitory concentration (MIC) values and the microorganisms used (seven Gram-negative bacteria and one Gram-positive bacterium) are shown in Table 4. The A. cherimola essential oil reported MIC values of $500 \mu \mathrm{g} / \mathrm{mL}$ against Campylobacter jejuni (ATCC 33560). EO dissolved in aqueous media caused the formation of an emulsion that difficulted the visual observation of bacterial growth particularly with $C$. jejuni. The reduction of 2,3,5-Triphenyl tetrazolium chloride 
(TTZ) yield a red color product only in the wells were bacteria developed a well growth. A blank of EO with the same range of concentrations and media was included to discard interferences due to contamination which was also confirmed by reading at $405 \mathrm{~nm}$ (data not shown) For the other bacteria, the essential oil did not show activity at the maximum dose tested.

Table 3. Enantiomeric distribution of chiral constituents occurring in the $\mathrm{EO}$ of $A$. cherimola.

\begin{tabular}{|c|c|c|c|c|}
\hline Enantiomers & $\begin{array}{l}\text { RT } \\
\text { min }\end{array}$ & RI & $\begin{array}{c}\text { Enantiomeric Distribution } \\
\%\end{array}$ & $\begin{array}{l}\text { e.e. } \\
\%\end{array}$ \\
\hline$(+)$ - $\alpha$-Pinene $(1 \mathrm{R}, 5 \mathrm{R})$ & 4.60 & 916 & 18.01 & \multirow{2}{*}{63.99} \\
\hline$(-)$ - $\alpha$-Pinene $(1 S, 5 S)$ & 5.10 & 921 & 81.99 & \\
\hline$(-)-\beta$-Pinene $(1 S, 5 S)$ & 10.01 & 970 & 100.00 & 100.00 \\
\hline (+)-Sabinene $(1 \mathrm{R}, 5 \mathrm{R})$ & 10.51 & 975 & 2.05 & \multirow[b]{2}{*}{95.91} \\
\hline (-)-Sabinene $(1 S, 5 S)$ & 10.91 & 979 & 97.95 & \\
\hline$(-)$-Limonene $(4 S)$ & 16.72 & 1037 & 63.75 & \multirow{2}{*}{27.50} \\
\hline (+)-Limonene (4R) & 17.22 & 1042 & 36.25 & \\
\hline (+)-Germacrene D (8R) & 61.61 & 1485 & 2.05 & \multirow[b]{2}{*}{95.91} \\
\hline (-)-Germacrene D (8S) & 62.01 & 1489 & 97.95 & \\
\hline
\end{tabular}

Table 4. Antibacterial activity of essential oil from Annona cherimola leaves.

\begin{tabular}{ccc}
\hline Bacteria & Annona cherimola & Positive Control $^{\text {a }}$ \\
\cline { 2 - 3 } & \multicolumn{2}{c}{ MIC $(\mu \mathrm{g} / \mathbf{m L})$} \\
\hline Gram-negative & 500 & 15.65 \\
Campylobacter jejuni (ATCC 33560) & $>1000$ & 1.95 \\
Escherichia coli (ATCC 25922) & 500 & 1.95 \\
Klebsiella pneumoniae (ATCC 9997) & $>1000$ & 7.81 \\
Proteus vulgaris (ATCC 8427) & $>1000$ & 15.62 \\
Pseudomonas aeruginosa (ATCC 27853) & $>1000$ & 3.90 \\
Salmonella typhimurium (LT2) & $>1000$ & 1.95 \\
Salmonella enterica (ATCC 29212) & & 1.95 \\
Gram-positive & $>1000$ & \\
Staphylococcus aureus (ATCC 25923)
\end{tabular}

${ }^{a}$ Erythromycin for Campylobacter jejuni and tetracycline for other bacteria.

\subsection{Antioxidant Capacity}

The results obtained for DPPH and ABTS radical scavenging of the EO are shown in Table 5. The results are expressed as the concentration of the $\mathrm{EO}$ that scavenge or decrease the concentration of the radical at $50 \%\left(\mathrm{SC}_{50}\right)$. Trolox was used as a positive control.

Table 5. Antioxidant activity of essential oils of Annona cherimola.

\begin{tabular}{ccc}
\hline Sample & DPPH & ABTS \\
\cline { 2 - 4 } & \multicolumn{2}{c}{ SC $_{\mathbf{5 0}}(\boldsymbol{\mu g} / \mathbf{m L})$} \\
\hline Essential oil & $470 \pm 30$ & $>1000$ \\
Trolox & $232 \pm 20$ & $446 \pm 30$ \\
\hline
\end{tabular}

Through the DPPH method, the essential oils of $A$. cherimola showed strong antioxidant activity with a $\mathrm{SC}_{50}$ value of $470 \pm 30 \mu \mathrm{g} / \mathrm{mL}$. Employing the ABTS technique the $\mathrm{SC}_{50}$ could not be calculated at the concentration ranges tested (Figure 1).

\subsection{Anticholinesterase Activity}

Three different concentrations of the essential oil from $A$. cherimola leaves were used to determine its anticholinesterase potential. The data obtained by measuring the rate of reaction of AChE against EO are shown in Figure 2. The results plotted as Log (concentration 
essential oil) vs. normalized response rate of reaction allowed us to calculate the $\mathrm{IC}_{50}$ value. The $\mathrm{IC}_{50}$ value obtained for chirimoya essential oil was $41.51 \pm 1.02 \mu \mathrm{g} / \mathrm{mL}$. The positive control (donepezil) exhibited an $\mathrm{IC}_{50}$ value of $13.80 \pm 1.01 \mathrm{nM}$.
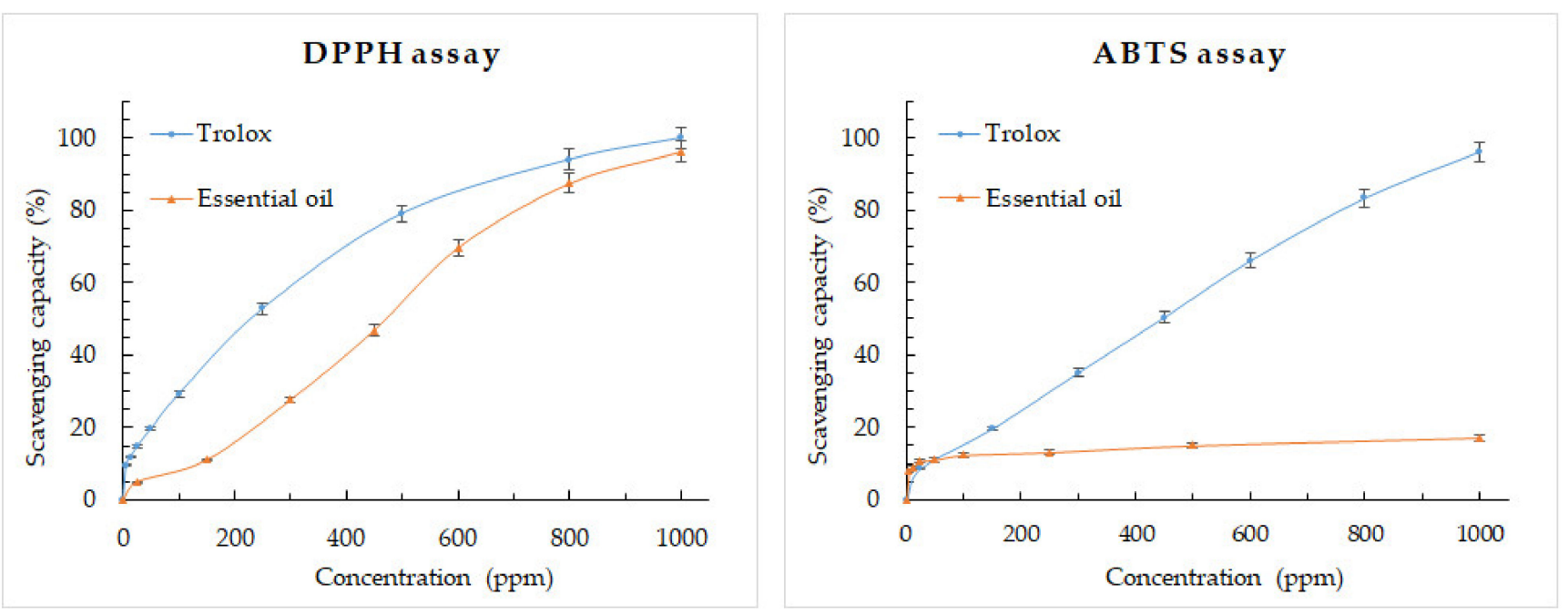

Figure 1. Scavenging capacity vs. concentration of Annona cherimola essential oil obtained by DPPH and ABTS assays.

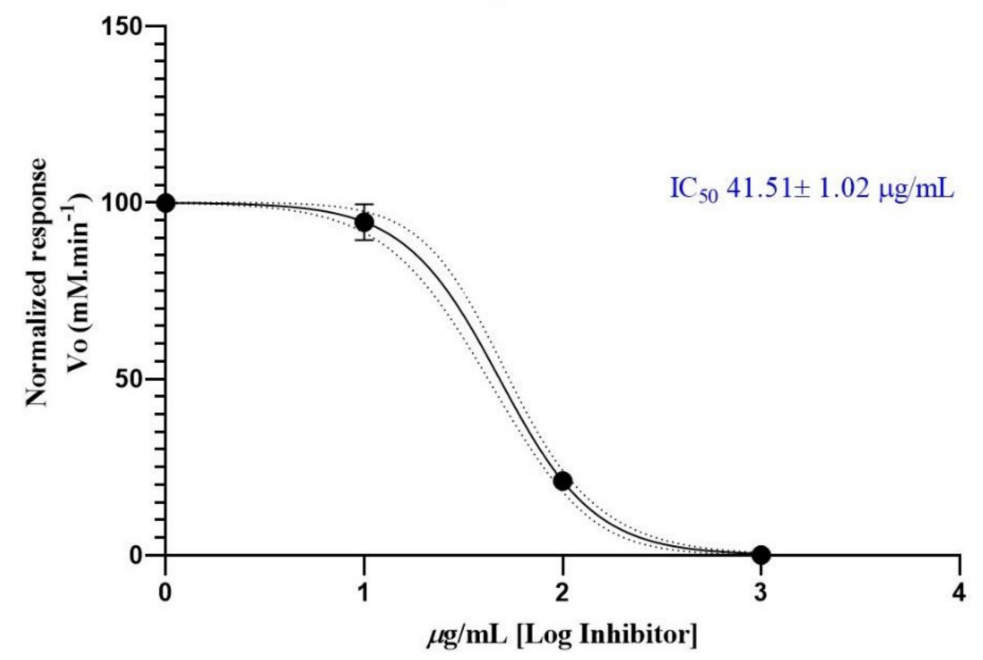

Figure 2. Half-maximum inhibitory concentration of Annona cherimola essential oil against acethylcholinesterase.

\section{Discussion}

The essential oil from Annona cherimola exhibited a low yield of $2.5 \pm 0.2 \mathrm{~mL} / \mathrm{Kg}$ [17]. The extraction yield of essential oils is very variable between plant species and depends on different aspects related to the plant such as the part, the age and the time after plant collection and other aspects related to the isolation process such as the pretreatment of the material (drying, grinding, etc.) and the extraction time [18].

The aroma of the Annona species is well recognized and has been studied in some species, however, little has been reported about the essential oil composition of Annona cherimola. In the present study, the main chemical components identified were aliphatic monoterpenes $(25.68 \%)$ and aliphatic sesquiterpenes $(69.40 \%)$, which was similar to the information reported by Rabelo et al. [19]. Furthermore, Rios et al. in 2003 [20] reported monoterpenes $(6.09 \%)$ and sesquiterpenes $(76.56 \%)$ as the main type of compounds in the 
A. cherimola EO. On the other hand, the same type of volatile compounds were meaningful in fruits of Annona cherimola (monoterpene 40.3\% and sesquiterpene 24.3\%) [16].

The major components $(>5 \%)$ identified in the A. cherimola EO were germacrene D $(28.77 \%)$, bicyclogermacrene $(11.12 \%),(E)$-caryophyllene $(10.52 \%)$, sabinene $(9.05 \%)$ and $\beta$ pinene $(7.93 \%)$. The results are different to those reported by Elhawary et al. $\mathrm{f} \beta$-caryophyllene with $9.50 \%$, germacrene-D with $17.71 \%$ an $\beta$-elemene with $25.02 \%$ [21], and those reported by Rios et al. reported bicyclogermacrene (18.20\%), trans-caryophyllene $(11.50 \%), \alpha$-amorphene $(7.57 \%), \alpha$-copaene $(5.63 \%)$ and germacrene D (3.75\%) [20]. In addition, Pino observed that the major compounds were $\alpha$-thujene (18.7 ppm), $\alpha$-pinene (23 ppm), terpinen-4-ol $(19.8 \mathrm{ppm})$ and germacrene D (17.6 ppm) [16]. Despite the differences in their concentrations, the main component that is common in all the studies is germacrene $\mathrm{D}$. It is well known the influence of different cultivation and climatic factors over the chemical composition of the essential oils.

Due to the relevance of aromatic compounds of the Annona species Ferreira et al. in 2009 compared the essential oil and the volatile compounds of the leaves and fruits of Annona cherimola. The chemical composition for the EO was different to the volatile compounds in fruits, the main compounds in the leaves essential oil were identified in lower quantities, germacrene-D $(0.11 \%$ to $0.22 \%)$, sabinene (not identified), $\beta$-pinene $(0.79 \%$ to $3.60 \%)$, (E)-caryophyllene ( $0.23 \%$ to $0.32 \%$ ) and bicyclogermacrene (not identified) while the main compounds analyzed by headspace solid phase microextraction were methyl butanoate, butyl butanoate, 3-methylbutyl butanoate, 3-methylbutyl 3-methylbutanoate and 5-hydroxymethyl-2-furfural [22].

This is the first report of enantioselective GC-MS analysis of $A$. cherimola EO, this analysis showed the ocurrence of five pairs of enantiomers and one enantiomerically pure chiral monoterpenoid, $\beta$-pinene. The enantiomeric ratio of an essential oil is an important information which could be related with the biological activity, metabolism and organoleptic quality of the enantiomeric pairs [23]. The enantiomeric excess (e.e \%) were $(-)-\alpha$-pinene $(1 \mathrm{~S}, 5 \mathrm{~S})(63.99 \%),(-)$-sabinene $(1 \mathrm{~S}, 5 \mathrm{~S})(95.91 \%),(-)$-limonene $(4 \mathrm{R})(27.50 \%)$ and (-)-germacrene D (8S) (95.91\%).

Regarding their biological activity, the essential oil of Annona cherimola showed moderate antibacterial activity against Campylobacter jejuni (ATCC 33560) and Klebsiella pneumonia (ATCC 9997), both with MIC at $500 \mu \mathrm{g} / \mathrm{mL}$ and no activity for the other bacteria tested (MIC was higher than $1000 \mu \mathrm{g} / \mathrm{mL}$ ). Compared to data reported in the literature, Rios et al. in 2003 reported a significant activity against two Gram-positive bacteria Staphylococcus aureus (MIC $250 \mu \mathrm{g} / \mathrm{mL}$ ) and Enterococcus faecalis (MIC $500 \mu \mathrm{g} / \mathrm{mL}$ ), however, the MIC values for Gram-negative bacteria were higher than $5000 \mu \mathrm{g} / \mathrm{mL}$ [20]. Elhawary et al. in 2013 reported the MIC of EO A. cherimola for Bacillus subtilis $(130 \mu \mathrm{g} / \mathrm{mL})$, Staphylococcus aureus $(285 \mu \mathrm{g} / \mathrm{mL})$, Escherichia coli $(110 \mu \mathrm{g} / \mathrm{mL})$, Pseudomonas aeruginosa $(140 \mu \mathrm{g} / \mathrm{mL})$, and Candida albicans $(152 \mu \mathrm{g} / \mathrm{mL})$ [21]. When the antibacterial activity of pure compounds was analyzed [20] the MIC of trans-caryophyllene, $\beta$-pinene, linalool, and other compounds was higher than the value for the essential oil, therefore suggesting that the antibacterial potency could be exerted by a synergistic effect among the constituents above mentioned. The essential oil of Annona species showed a wide range of biological activity, for A. vepretorum Costa et al. in 2012 reported a moderate activity (MIC $500 \mu \mathrm{g} / \mathrm{mL}$ ) against Staphylococcus aureus and Staphylococcus epidermis and a significant activity against Candida tropicalis (MIC $100 \mu \mathrm{g} / \mathrm{mL}$ ) [24]. Another study, in 2013, Costa et al. observed the antibacterial activity of essential oil of A. salzmannii and A. pickelii against Staphylococcus aureus, Staphylococcus epidermis and Candida tropicalis with MIC of $500 \mu \mathrm{g} / \mathrm{mL}$ [25].

Some studies have shown that the enantiomers of a compound have different biological activities. Lis-Balcnin et al. reported that 18 out of 25 different bacteria were more affected by the (-)- $\alpha$-pinene in comparison with the (+) enantiomer, 19 out of 20 different Listeria monocytogenes strains were affected more by $(+)-\alpha$-pinene isomer and two of three filamentous fungi were affected more by the $(+)$ enantiomer [26]. The MIC and minimal 
microbicidal concentration (MMC) showed that the positive enantiomers of pinene exerted a microbicidal effect against all the fungi and bacteria tested with MIC values ranging from 117 to $4150 \mu \mathrm{g} / \mathrm{mL}$. However, with concentrations up to $20 \mathrm{mg} / \mathrm{mL}$ of the negative enantiomers, no antimicrobial activity was observed [27]. The MIC values against three Gram-positive (B. cereus, E. faecalis and S. aureus) and four Gram-negative (E. coli, K. pneumoniae, M. catarrhalis and P. aeruginosa) bacteria were in the ranges of 3 to $27 \mathrm{mg} / \mathrm{mL}$ for (+)-limonene and 2 to $27 \mathrm{mg} / \mathrm{mL}$ for (-)-limonene. The greatest difference was obtained against Staphylococcus aureus ATCC 12600 where the (+)-limonene showed a MIC of $14 \mathrm{mg} / \mathrm{mL}$ and the (-)-limonene a MIC of $4 \mathrm{mg} / \mathrm{mL}$ [28]. Omran et al. found that (-)-limonene had better antifungal activity than (+)-limonene against Aspergillus niger, Aspergillus sp., Candida albicans and Penicillium sp. [29]. It was not possible to find previous studies about the antifungal or antibacterial activity of the $(+)$ and $(-)$ enantiomers of the main compound germacrene D, however, Stranden et al. determined that the two enantiomers of this compound mediate the same kind of information to the receptor neurons of the moth Helicoverpa armigera, but (-)-germacrene D had approximately 10 times stronger effect than (+)-germacrene D [30]. The difference in biological activity of the enantiomers is maintained even when they are mixed with other compounds [28]. The enantiomers of a compound have different biological activities, then, the enantiomeric distribution of the compounds could influence the biological activity for an essential oil.

Regarding their antioxidant effect, the Annona cherimola essential oil showed an $\mathrm{SC}_{50}$ of $470 \mu \mathrm{g} / \mathrm{mL}$ for the DPPH assay while the $\mathrm{SC}_{50}$ was $>1000 \mu \mathrm{g} / \mathrm{mL}$ in the ABTS assay. Costa et al. reported as strong the antioxidant activity of EO A. salzamannii and A. pickelii measured by a TLC-based DPPH assay, however, the individual components $\beta$-pinene and $\alpha$-pinene did not show antioxidant activity [25]. Araújo, et al. [31] and Costa, et al. [24] reported a weak antioxidant activity for the $\mathrm{EO}$ of $A$. vepretorum. Another study, Gyesi, et al. in 2019 [32] reported an $\mathrm{SC}_{50}$ of $244.8 \mu \mathrm{g} / \mathrm{mL}$ from the DPPH assay for the EO of $A$. muricata. The differences between the antioxidant activity of $\mathrm{EO}$ and pure compounds could correspond to synergistic effects among the components in the essential oil.

The acetylcholinesterase inhibitory activity of $A$. cherimola $\mathrm{EO}$ has not been previously reported. Chirimoya $\mathrm{EO}$ showed an $\mathrm{AChE} \mathrm{IC}_{50}$ value of $41.51 \mu \mathrm{g} / \mathrm{mL}$, this inhibitory activity could be considered very strong compared to the related EO of Piper carpunya $\left(\mathrm{IC}_{50}\right.$ of $\left.36.42 \mu \mathrm{g} / \mathrm{mL}\right)$ [33]. The inhibition of $\mathrm{AChE}$ due to $\mathrm{EO}$ is of relevant interest in the treatment of Alzheimer disease since different studies report in vitro and clinical AChE inhibitory activity. Benny and Tomas summarize the neuroprotective effects of EO and its relevance on Alzheimer disease stating that $\mathrm{EO}$ could rebuild the antioxidant status of brain which confer neuroprotective effect as in the case of EO of Coriandrum sativum L., Syzygium aromaticum (L.), Juniperus communis, Rosmarinis officinalis (L.), and other species. The same activity has been observed for pure compounds such as thymol, linalool, $\alpha-$ terpinene, $\alpha$-terpineol, carvacrol, (E)- $\beta$-caryophyllene, $\alpha$-pinene, and eugenol [34].

\section{Materials and Methods}

\subsection{Materials}

Dichloromethane (DMC), methanol $(\mathrm{MeOH})$, sodium sulfate anhydrous, DPPH (2,2diphenyl-1-picrylhydryl), ABTS (2,2'-azinobis-3-ethylbenzothiazoline-6-sulfonic acid), acetylcholinesterase (AChE), acetylthiocholine (ATC), phosphate buffered saline, Ellman's reagent (donepezil, 5,5'-dithiobis(2-nitrobenzoic acid)), tris hydrochloride (Tris- $\mathrm{HCl}$ ), magnesium chloride hexahydrate and 2,3,5-Triphenyl tetrazolium chloride (TTZ) were purchased from Sigma-Aldrich (San Luis, MO, USA). The microbiological media such as Mueller Himton broth, Mueller Hinton II broth and fluid thioglycollate medium were purchased from DIPCO (Quito, Ecuador). Horse serum and Oxoid CampyGen were purchased from Thermo Fisher Scientific (Waltham, MA, USA). The standard aliphatic hydrocarbons were purchased from ChemService (West Chester, PA, USA). Helium was purchased from INDURA (Quito, Ecuador). All chemicals were of analytical grade and used without further purifications. 


\subsection{Plant Material}

Annona cherimola leaves were collected under permission granted for Ministerio del Ambiente de Ecuador (Ecuadorian Environmental Ministry) by means of the authorization No. 001-IC-FLO-DBAP-VS-DRLZCH-MA. The leaves of chirimoya were collected between the months of October and January in the surroundings of the locality of Cango Bajo, canton Calvas, province of Loja, Ecuador, at $1950 \mathrm{~m}$ a.s.l. at a latitude of $4^{\circ} 20^{\prime} 34^{\prime \prime} \mathrm{S}$ and a longitude of $79^{\circ} 34^{\prime} 24^{\prime \prime} \mathrm{W}$. Collection, store and transfer of chirimoya leaves were performed according to what is described by Valarezo et al. [35]. Botanist Nixon Cumbicus made the identification of the plant material. A voucher specimen was deposited at the Herbarium of Universidad Técnica Particular de Loja (HUTPL).

\subsection{Postharvest Treatments}

Between 2 and $3 \mathrm{~h}$ after being collected, the plant material was subjected to the postharvest treatments, which consist of the separation of degraded leaves and foreign material.

\subsection{Moisture Determination}

Method Loss on drying (Moisture) in plants, AOAC 930.04-1930, was used to determine the moisture of plant material, for this an analytical balance (Mettler AC 100, Mettler Toledo, Columbus, $\mathrm{OH}$, USA) was used. Moisture was calculated according to Equation (1).

$$
\text { Moisture }(\%)=\frac{\mathrm{wi}-\mathrm{wo}}{\mathrm{wi}} * 100
$$

where wi is the initial weight of sample and wo is weight of sample after drying.

\subsection{Essential Oil Extraction}

The isolation of the essential oil from leaves of $A$. cherimola was carried out by hydrodistillation using a Clevenger-type apparatus according to the procedure described by Valarezo et al. [36]. After being collected, the essential oil was dried using anhydrous sodium sulphate. Finally, the EO was stored at $4{ }^{\circ} \mathrm{C}$ in amber sealed vials until being used in the subsequent analysis.

\subsection{Determination of the Physical Properties of the Essential Oil}

Density of the essential oil was determined using the ISO 279:1998 standard (equivalent to the AFNOR NF T 75-111 standard). Density measurement was performed using an analytical balance (Mettler AC 100, Mettler Toledo, Columbus, OH, USA) and a pycnometer of $1 \mathrm{~mL}$. Refractive index was determined using the standard ISO 280:1998 [37] (similary to AFNOR NF T 75-112), for which a refractometer (model ABBE, BOECO, Hamburg, Germany) was used. An automatic polarimeter (Mrc-P810, MRC, Holon, Israel) was used to measure the optical rotation of the EO according to the standard ISO 592:1998. All measurements were taken at $20^{\circ} \mathrm{C}$.

\subsection{Identification of the Chemical Constituents of the Essential Oil \\ 4.7.1. Quantitative and Qualitative Analysis}

The dentification of the chemical constituents of the essential oil was carried out using an Agilent gas chromatograph (GC) (6890N series, Agilent Technologies, Santa Clara, CA, USA). For the quantitative analysis gas chromatograph was equipped with a flame ionization detector (FID) and for qualitative analysis gas chromatograph was coupled to a mass spectrometer (quadrupole) detector (MS) (model Agilent 5973 inert series, Agilent Technologies, Santa Clara, CA, USA). The GC-FID and GC-MS analyses were performed according to the procedure described by Valarezo et al. [35]. The injection of the samples was carried out by an automatic injector (Agilent 7683 automatic liquid sampler, Agilent Technologies, Santa Clara, CA, USA) in split mode. Chromatographic runs were performed using a nonpolar and a polar column. The nonpolar was an Agilent J\&W DB-5ms Ultra Inert GC column with stationary phase 5\%-phenyl-methylpolyxilosane and 
the polar was an Agilent J\&W HP-INNOWax GC column with stationary phase polyethylene glycol. Both columns with a length of $30 \mathrm{~m}$, an outer diameter of $0.25 \mathrm{~mm}$ and a stationary phase thickness of $0.25 \mu \mathrm{m}$. Identification of the $\mathrm{EO}$ compounds was based on a comparison of relative retention indices (RIs) and mass spectra data with those of the published literature [38,39] according as described by Valarezo et al. [36].

\subsubsection{Enantioselective Analysis}

The enantiomeric distribution was performed using an enantioselective column with stationary phase 2,3-diethyl-6-tert-butyldimethylsilyl- $\beta$-cyclodextrin. The chromatographic run was performed with a temperature ramp of $2{ }^{\circ} \mathrm{C} / \mathrm{min}$ from $50{ }^{\circ} \mathrm{C}$ (maintained for $2 \mathrm{~min}$ ) to $220^{\circ} \mathrm{C}$ (maintained for $2 \mathrm{~min}$ ) in an Agilent gas chromatograph (model 6890N series, Agilent Technologies, Santa Clara, CA, USA) coupled to a mass spectrometer (quadrupole) detector (model Agilent 5973 inert series, Agilent Technologies, Santa Clara, CA, USA). The injection of enantiomerically pure standards was used to determine the order of elution of the enantiomers.

\subsection{Evaluation of Antibacterial Activity}

The antibacterial activity of the essential oil from chirimoya leaves was assessed against Gram-negative and Gram-positive bacteria (Table 4) by the microdilution broth method according to the procedure described by Valarezo et al. [40]. The bacterial strains were incubated in Müeller-Hinton (MH) broth. Tetracycline was used as a positive control and DMSO was used as a negative control. Results are reported as minimum inhibitory concentration (MIC).

For Campylobacter jejuni (ATCC 33560) the broth microdilution method was carried out according to Valarezo et al. [40] with some specific requirements as described briefly. Fluid thioglycollate medium was used for reactivation of the strain, supplemented with $5 \%$ of Horse serum. An aliquot of a cryogenic reserve was resuspended in thioglycollate and incubated for $48 \mathrm{~h}$ at $37^{\circ} \mathrm{C}$ in a microaerophilic atmosphere provided by an Oxoid CampyGen (2.5 L sachet). Sample solutions were made by dissolving $80 \mathrm{mg}$ of EO in $1 \mathrm{~mL}$ of DMSO. Two-fold serial dilutions were employed to obtain decreasing concentrations of EO from 4000 to $31.25 \mu \mathrm{g} / \mathrm{mL}$ and cation-adjusted Muller Hinton II broth (pH 7.3) with 5\% lyssed horse blood [41] as media for the antibacterial assay. The inoculum was prepared from thioglycollate culture and adjusted to $0.5 \mathrm{McF}$ arland. Final concentration of bacteria was $5 \times 10^{5} \mathrm{CFU} / \mathrm{mL}$. The microplate was incubated for $48 \mathrm{~h}$ at $37^{\circ} \mathrm{C}$ in microaerophilic atmosphere ( $5 \% \mathrm{CO}_{2}$, Oxoid CampyGen). Erythromycin was used as positive control with a MIC value of $15.65 \mu \mathrm{g} / \mathrm{mL}$ and DMSO as negative control. MIC was determined by visual examination of growth and through addition of a $1 \%$ solution of TTZ as bacterial viability indicator after incubation time to confirm the visual results. A blank with the same range of concentrations of EO was prepared simultaneously and measurements at $405 \mathrm{~nm}$ were made to discard reduction of TTZ by contamination. Optical density (OD) for TTZ reduction was measured in a microplate reader (EPOCH 2, BioTek, Winooski, VT, USA).

\subsection{Antioxidant Capacity \\ 4.9.1. DPPH Radical Scavenging Capacity}

The DPPH assay was performed using 2,2-diphenyl-1-picrylhydryl free radical (DPPH $\left.{ }^{\bullet}\right)$ based on the technique described by Brand Williams et al. [42] and Thaipong et al. [43] according to what was described by Valarezo et al. [33]. The concentrations of the EO from $A$. cherimola leaves used were 1000, 800, 600, 450, 300, 150 and 25 ppm. Trolox was used as a positive control and methanol as a blank control. The samples were evaluated in a UV spectrophotometer (Genesys 10S UV.Vis Spectrophotometer, Thermo Scientific, Waltham, MA, USA) at a wavelength of $515 \mathrm{~nm}$. The percentage of scavenging capacity 
was calculated according to Equation (2). $\mathrm{SC}_{50}$ is the $\mathrm{EO}$ concentration that provided $50 \%$ $\mathrm{DPPH}^{\bullet}$ scavenging effect.

$$
\mathrm{SC}(\%)=\frac{(\mathrm{AEO}-\mathrm{AMeOH})}{\mathrm{AEO}} * 100
$$

where AEO is the absorbance of $\mathrm{DPPH}^{\bullet}$ mixed with EO and As is absorbance of DPPH mixed with methanol.

\subsubsection{ABTS Radical Cation Scavenging Capacity}

The ABTS assay was performed using 2,2'-azinobis-3-ethylbenzothiazoline-6-sulfonic acid radical cation $\left(\mathrm{ABTS}^{\bullet+}\right.$ ) according to the procedure report by Arnao et al. [44] and Thaipong et al. [43], as described by Valarezo et al. [33]. The concentrations of the essential oil from A. cherimola used were 1000, 500, 250, 100, 50 and $25 \mathrm{ppm}$. The samples were evaluated in a UV spectrophotometer (Genesys 10S UV.Vis Spectrophotometer, Thermo Scientific, Waltham, MA, USA) at a wavelength of $734 \mathrm{~nm}$. Deionized water was used as a blank control and trolox was used as a positive control. The percentage of scavenging capacity was calculated according to equation.

$$
\mathrm{Sc}(\%)=\frac{(\mathrm{ASO}-\mathrm{ASA})}{\mathrm{ASA}} * 100
$$

where ASO is the absorbance of $\mathrm{ABTS}^{\bullet+}$ with solvent mixture and $\mathrm{Ai}$ is the absorbance after reaction of $\mathrm{ABTS}^{\bullet+}$ with the sample.

\subsection{Anticholinesterase Activity}

The AChE inhibitory effect was measured based on the methodology designed by Ellman, et al. [45], with slight modifications as suggested by Rhee, et al. [46], as previously described by Valarezo et al. [33]. The inhibition of AChE was detected after the addition of Acetylthiocholine as the enzyme substrate and several concentrations of EO dissolved in $\mathrm{MeOH}$. The enzyme reaction was monitored in a microplate reader (EPOCH 2, BioTek, Winooski, VT, USA) at $405 \mathrm{~nm}$ for $60 \mathrm{~min}$. Final concentrations of 1000, 100, and $10 \mu \mathrm{g} / \mathrm{mL}$ of the $\mathrm{EO}$ in $\mathrm{MeOH}$ were prepared to assess the enzyme inhibition. The assay was carried out by triplicate in 96-well microplates. Donepezil was used as positive control. The $\mathrm{IC}_{50}$ value was calculated from the progression curve with the Graph Pad Prism software (v8.0.1.5., Graph Pad, San Diego, CA, USA)

\subsection{Statistical Analysis}

All procedures were repeated three times, except for the biological activity, which was repeated nine times. Microsoft Excel was used to collect the data and Minitab 17 (Version 17.1.0., Minitab LLC., State College, PA, USA) was used to calculate the measures of central tendency. The results are expressed as mean values.

\section{Conclusions}

Enantiomeric distribution, antibacterial activity against Campylobacter jejuni, antioxidant and anticholinesterase activities of the essential oil from Annona cherimola leaves were determined for the first time, in addition, the chemical composition and physical properties of this essential oil was studied. This research contributes to our knowledge about native species of Ecuador. The results obtained in this study motivate us to carry out new investigations in endemic and native species of this megadiverse country.

Author Contributions: Conceptualization, E.V. and V.M.; methodology, J.L., L.C., J.C. and M.A.M.; validation, E.V. and V.M.; formal analysis, J.L., E.E.-C., J.C., L.C. and M.A.M.; investigation, J.L., E.E.-C., M.A.M., L.C. and J.C.; resources, E.V.; data curation, V.M. and E.V.; writing-original draft preparation, M.A.M.; writing-review and editing, L.C. and E.V.; project management, V.M. and E.V. All authors have read and agreed to the published version of the manuscript. 
Funding: This research received no external funding.

Institutional Review Board Statement: Not applicable.

Informed Consent Statement: Not applicable.

Data Availability Statement: Data are available from the authors upon reasonable request.

Acknowledgments: The authors are very grateful with the Ecuadorian Environmental Ministry (Ministerio del Ambiente de Ecuador, MAE) for the permission granted.

Conflicts of Interest: There is no conflict of interest to declare.

\section{References}

1. The Plant List. Annonaceae. Available online: http://www.theplantlist.org/ (accessed on 12 September 2021).

2. Jørgesen, P.M.; León-Yáñez, S. Catalogue of the Vascular Plants of Ecuador. Available online: http://legacy.tropicos.org/ ProjectAdvSearch.aspx?projectid=2 (accessed on 11 July 2020).

3. Frausin, G.; Lima, R.B.S.; Hidalgo, A.F.; Maas, P.; Pohlit, A.M. Plants of the annonaceae traditionally used as antimalarials: A review. Rev. Bras. Frutic. 2014, 36, 315-337. [CrossRef]

4. Tajbakhsh, E.; Kwenti, T.E.; Kheyri, P.; Nezaratizade, S.; Lindsay, D.S.; Khamesipour, F. Antiplasmodial, antimalarial activities and toxicity of African medicinal plants: A systematic review of literature. Malar. J. 2021, 20, 349. [CrossRef] [PubMed]

5. Santos-Sánchez, N.F.; Salas-Coronado, R.; Hernández-Carlos, B.; Pérez-Herrera, A.; Rodríguez-Fernández, D.J. Biological Activities of Plants from Genus Annona; IntechOpen: London, UK, 2018; p. 168.

6. Moghadamtousi, S.Z.; Fadaeinasab, M.; Nikzad, S.; Mohan, G.; Ali, H.M.; Kadir, H.A. Annona muricata (Annonaceae): A Review of Its Traditional Uses, Isolated Acetogenins and Biological Activities. Int. J. Mol. Sci. 2015, 16, 15625. [CrossRef] [PubMed]

7. Chowdhury, S.S.; Tareq, A.M.; Tareq, S.M.; Farhad, S.; Sayeed, M.A. Screening of antidiabetic and antioxidant potential along with phytochemicals of Annona genus: A review. Future J. Pharm. Sci. 2021, 7, 144. [CrossRef]

8. Arunjyothi, B.; Venkatesh, K.; Chakrapani, P.; Anupalli, R.R. Phytochemical and Pharmacological potential of Annona cherimola-A Review. Int. J. Phytomed. 2012, 3, 9.

9. Gayoso Bazán, G.; Chang Chávez, L. Annona cherimola Mill. "chirimoya” (Annonaceae), una fruta utilizada como alimento en el Perú prehispánico. Arnaldoa 2017, 24, 619-634. [CrossRef]

10. Gupta-Elera, G.; Garrett, A.R.; Martinez, A.; Robison, R.A.; O'Neill, K.L. The antioxidant properties of the cherimoya (Annona cherimola) fruit. Food Res. Int. 2011, 44, 2205-2209. [CrossRef]

11. Chen, C.-Y.; Chang, F.-R.; Pan, W.-B.; Wu, Y.-C. Four alkaloids from Annona cherimola. Phytochemistry 2001, 56, 753-757. [CrossRef]

12. Chen, C.-Y.; Chang, F.-R.; Wu, Y.-C. Cherinonaine, a novel dimeric amide from the stems of Annona cherimola. Tetrahedron Lett. 1998, 39, 407-410. [CrossRef]

13. Díaz-de-Cerio, E.; Aguilera-Saez, L.M.; Gómez-Caravaca, A.M.; Verardo, V.; Fernández-Gutiérrez, A.; Fernández, I.; Arráez-Román, D. Characterization of bioactive compounds of Annona cherimola L. leaves using a combined approach based on HPLC-ESI-TOF-MS and NMR. Anal. Bioanal. Chem. 2018, 410, 3607-3619. [CrossRef]

14. Albuquerque, T.G.; Santos, F.; Sanches-Silva, A.; Beatriz Oliveira, M.; Bento, A.C.; Costa, H.S. Nutritional and phytochemical composition of Annona cherimola Mill. fruits and by-products: Potential health benefits. Food Chem. 2016, 193, 187-195. [CrossRef] [PubMed]

15. Ammoury, C.; Younes, M.; El Khoury, M.; Hodroj, M.H.; Haykal, T.; Nasr, P.; Sily, M.; Taleb, R.I.; Sarkis, R.; Khalife, R.; et al. The pro-apoptotic effect of a Terpene-rich Annona cherimola leaf extract on leukemic cell lines. BMC Complement. Altern. Med. 2019, 19, 365. [CrossRef] [PubMed]

16. Pino, J.A. Volatile Components of Cuban Annona Fruits. J. Essent. Oil Res. 2000, 12, 613-616. [CrossRef]

17. Molares, S.; González, S.B.; Ladio, A.; Agueda Castro, M. Etnobotánica, anatomía y caracterización físico-química del aceite esencial de Baccharis obovata Hook. et Arn. (Asteraceae: Astereae). Acta Bot. Bras. 2009, 23, 578-589. [CrossRef]

18. Valarezo, E.; Ojeda-Riascos, S.; Cartuche, L.; Andrade-González, N.; González-Sánchez, I.; Meneses, M.A. Extraction and Study of the Essential Oil of Copal (Dacryodes peruviana), an Amazonian Fruit with the Highest Yield Worldwide. Plants 2020, 9, 1658. [CrossRef]

19. Rabelo, S.V.; Quintans, J.d.S.S.; Costa, E.V.; Guedes da Silva Almeida, J.R.; Quintans Júnior, L.J. Chapter 24-Annona Species (Annonaceae) Oils. In Essential Oils in Food Preservation, Flavor and Safety; Preedy, V.R., Ed.; Academic Press: San Diego, CA, USA, 2016; pp. 221-229. [CrossRef]

20. Ríos, M.Y.; Castrejón, F.; Robledo, N.; León, I.; Rojas, G.; Navarro, V. Chemical Composition and Antimicrobial Activity of the Essential Oils from Annona cherimola (Annonaceae). Rev. Soc. Quim. Mex. 2003, 47, 139-142.

21. Elhawary, S.S.; El Tantawy, M.E.; Rabeh, M.A.; Fawaz, N.E. DNA fingerprinting, chemical composition, antitumor and antimicrobial activities of the essential oils and extractives of four Annona species from Egypt. J. Nat. Sci. Res. 2013, 13, 59-68. 
22. Ferreira, L.; Perestrelo, R.; Câmara, J.S. Comparative analysis of the volatile fraction from Annona cherimola Mill. cultivars by solid-phase microextraction and gas chromatography-Quadrupole mass spectrometry detection. Talanta 2009, 77, 1087-1096. [CrossRef]

23. Barba, C.; Santa-María, G.; Herraiz, M.; Martínez, R.M. Direct enantiomeric analysis of Mentha essential oils. Food Chem. 2013, 141, 542-547. [CrossRef]

24. Costa, E.V.; Dutra, L.M.; Nogueira, P.C.d.L.; Moraes, V.R.D.S.; Salvador, M.J.; Ribeiro, L.H.G.; Gadelha, F.R. Essential Oil from the Leaves of Annona vepretorum: Chemical Composition and Bioactivity. Nat. Prod. Commun. 2012, 7, 1934578X1200700240. [CrossRef]

25. Costa, E.V.; Dutra, L.M.; Salvador, M.J.; Ribeiro, L.H.G.; Gadelha, F.R.; de Carvalho, J.E. Chemical composition of the essential oils of Annona pickelii and Annona salzmannii (Annonaceae), and their antitumour and trypanocidal activities. Nat. Prod. Res. 2013, 27, 997-1001. [CrossRef] [PubMed]

26. Lis-Balcnin, M.; Ochocka, R.J.; Deans, S.G.; Asztemborska, M.; Hart, S. Differences in Bioactivity between the Enantiomers of

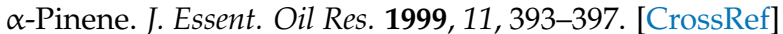

27. Silva, A.C.R.d.; Lopes, P.M.; Azevedo, M.M.B.d.; Costa, D.C.M.; Alviano, C.S.; Alviano, D.S. Biological Activities of a-Pinene and $\beta$-Pinene Enantiomers. Molecules 2012, 17, 6305-6316. [CrossRef] [PubMed]

28. Vuuren, S.F.v.; Viljoen, A.M. Antimicrobial activity of limonene enantiomers and 1,8-cineole alone and in combination Flavour Fragr. J. 2007, 22, 540-544. [CrossRef]

29. Mahdavi Omran, S.; Moodi, M.A.; Norozian Amiri, S.M.B.; Mosavi, S.J.; Ghazi Mir Saeed, S.A.M.; Jabbari Shiade, S.M.; Kheradi, E.; Salehi, M. The Effects of Limonene and Orange Peel Extracts on Some Spoilage Fungi. Int. J. Mol. Clin. Microbiol. 2011, 1, 82-86.

30. Stranden, M.; Borg-Karlson, A.-K.; Mustaparta, H. Receptor Neuron Discrimination of the Germacrene D Enantiomers in the Moth Helicoverpa armigera. Chem. Senses 2002, 27, 143-152. [CrossRef]

31. Araújo, C.d.S.; de Oliveira, A.P.; Lima, R.N.; Alves, P.B.; Diniz, T.C.; da Silva, A.J.R.G. Chemical constituents and antioxidant activity of the essential oil from leaves of Annona vepretorum Mart. (Annonaceae). Pharmacogn. Mag. 2015, 11, 615-618. [CrossRef]

32. Gyesi, J.N.; Opoku, R.; Borquaye, L.S. Chemical composition, total phenolic content, and antioxidant activities of the essential oils of the leaves and fruit pulp of Annona muricata L. (Soursop) from Ghana. Biochem. Res. Int. 2019, 2019, 4164576. [CrossRef]

33. Valarezo, E.; Rivera, J.X.; Coronel, E.; Barzallo, M.A.; Calva, J.; Cartuche, L.; Meneses, M.A. Study of Volatile Secondary Metabolites Present in Piper carpunya Leaves and in the Traditional Ecuadorian Beverage Guaviduca. Plants 2021, 10, 338. [CrossRef]

34. Benny, A.; Thomas, J. Essential oils as treatment strategy for Alzheimer's disease: Current and future perspectives. Planta Med. 2019, 85, 239-248. [CrossRef]

35. Valarezo, E.; Morocho, V.; Cartuche, L.; Chamba-Granda, F.; Correa-Conza, M.; Jaramillo-Fierro, X.; Meneses, M.A. Variability of the Chemical Composition and Bioactivity between the Essential Oils Isolated from Male and Female Specimens of Hedyosmum racemosum (Ruiz \& Pav.) G. Don. Molecules 2021, 26, 4613. [CrossRef]

36. Valarezo, E.; Gaona-Granda, G.; Morocho, V.; Cartuche, L.; Calva, J.; Meneses, M.A. Chemical Constituents of the Essential Oil from Ecuadorian Endemic Species Croton ferrugineus and Its Antimicrobial, Antioxidant and $\alpha$-Glucosidase Inhibitory Activity. Molecules 2021, 26, 4608. [CrossRef] [PubMed]

37. Association Française de Normalisation (AFNOR). Huiles Essentielles. Tome 1, Échantillonnage et Méthodes D'analyse; Paris-La Défense, AFNOR: Paris, France, 2000; p. 471.

38. Adams, R.P. Identification of Essential Oil Components by Gas Chromatography/Mass Spectrometry, 4th ed.; Allured Publishing Corporation: Carol Stream, IL, USA, 2007; p. 804.

39. NIST. Libro del Web de Química del NIST, SRD 69. in Base de Datos de Referencia Estándar del NIST Número 69. Available online: http:/ / webbook.nist.gov (accessed on 19 March 2021).

40. Valarezo, E.; Merino, G.; Cruz-Erazo, C.; Cartuche, L. Bioactivity evaluation of the native Amazonian species of Ecuador: Piper lineatum Ruiz \& Pav. essential oil. Nat. Volatiles Essent. Oils 2020, 7, 14-25. [CrossRef]

41. Ge, B.; Wang, F.; Sjölund-Karlsson, M.; McDermott, P.F. Antimicrobial resistance in Campylobacter: Susceptibility testing methods and resistance trends. J. Microbiol. Methods 2013, 95, 57-67. [CrossRef] [PubMed]

42. Brand-Williams, W.; Cuvelier, M.E.; Berset, C. Use of a free radical method to evaluate antioxidant activity. LWT Food Sci. Technol. 1995, 28, 25-30. [CrossRef]

43. Thaipong, K.; Boonprakob, U.; Crosby, K.; Cisneros-Zevallos, L.; Hawkins Byrne, D. Comparison of ABTS, DPPH, FRAP, and ORAC assays for estimating antioxidant activity from guava fruit extracts. J. Food Compos. Anal. 2006, 19, 669-675. [CrossRef]

44. Arnao, M.B.; Cano, A.; Acosta, M. The hydrophilic and lipophilic contribution to total antioxidant activity. Food Chem. 2001, 73, 239-244. [CrossRef]

45. Ellman, G.L.; Courtney, K.D.; Andres, V.; Featherstone, R.M. A new and rapid colorimetric determination of acetylcholinesterase activity. Biochem. Pharmacol. 1961, 7, 88-95. [CrossRef]

46. Rhee, I.K.; van de Meent, M.; Ingkaninan, K.; Verpoorte, R. Screening for acetylcholinesterase inhibitors from Amaryllidaceae using silica gel thin-layer chromatography in combination with bioactivity staining. J. Chromatogr. A 2001, 915, 217-223. [CrossRef] 